\title{
ASIDES IN TURKISH POLITICAL NEWSPAPER INTERVIEWS
}

\author{
Elçin ESMER ${ }^{1}$ 凶 (i) \\ ${ }^{1}$ Associate Professor, Dr. Faculty of Education, Mersin University, Turkey
}

Received 29 March 2021

Accepted 12 April 2021

Published 30 April 2021

\section{Corresponding Author}

Elçin ESMER, elciny@yahoo.com

DOI 10.29121/

granthaalayah.v9.i4.2021.3837

Funding: This research received no specific grant from any funding agency in the public, commercial, or not-for-profit sectors.

Copyright: (C) 2021 The Author(s). This is an open access article distributed under the terms of the Creative Commons Attribution License, which permits unrestricted use, distribution, and reproduction in any medium, provided the original author and source are credited.

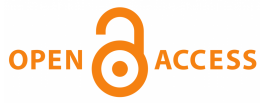

\section{ABSTRACT}

The newspaper genre is generally accepted as one of the most important examples of the persuasive text genre. 'Asides' are the short dialogues inserted by journalists to give their personal comments on the subject being reported. They therefore play a crucial role for journalists to persuade their readers and interact with them. Interviews are one of thecharacteristic features of newspaper discourse. This study examines the usage of asides in political interviews conducted with prominent politicians in Turkey. The data consisted of eighty political interviews published in seven elite mainstream newspapers which had different ideologies, four pro-government and three anti-government. In line with the aim of the study, the research uses a descriptive survey design. Quantitative and qualitative methods are applied using the methodologies of both Corpus Linguistics and Critical Discourse Analysis. The asides in the interviews are identified using Temmerman's (2013) classification of asidesand Hyland's (2005) taxonomy. Also, the corpus is analysed using the NooJ linguistic engine module. The results show that there are variations in the use and distribution of asides in the data according to the politicians' and the newspapers' ideologies.

Keywords: Asides, Interpersonal Metadiscourse, Political Interviews, Newspaper Discourse

\section{INTRODUCTION}

Metadiscourse or reflexive discourse is broadly defined as the discourse about discourse. The term 'metadiscourse' was coined by Harris (1959) to define the pragmatic relationship between writer and reader. Metadiscourse studies have been influenced by Halliday's (1972) functional approach to linguistics which considered language as a social semotic system. According to Halliday (1972), language cannot be separated from either its producers or its context and there are three basic functions which construct meaning in language: ideational, interpersonal and textual functions Halliday and owards a Sociological Semantics', Working Papers and Prepublications C014. Centro Internazionale di Semiotica e Linguistica, University di (1994); Hyland and Metadiscourse (2005) : 
1. The ideational function: language is a medium used to talk about experiences and happenings in the outside world and also our inner world;

2. The interpersonal function: language serves as a medium between individuals to establish and maintain social relations. In other words it is used to interact with others and influence their behavior and ideas in order to get their sympathy and help.

3. The textual function: this is about the flow of information in text. The function enables the speaker or writer to construct coherent texts, or connected passages of discourse.

Several metadiscourse taxonomies have been proposed (for example, Williams (n.d.) ; Kopple (1985) ; Crismore (1989) , Mauranen (1993) , Hyland and Metadiscourse (2005) , Ädel and A. Metadiscourse in L1 and L2 English (Vol. 24). John Benjamins Publishing; 2006 (2006) ). The first metadiscourse taxonomies were proposed by Williams (n.d.) , Kopple (1985) ) and Crismore (1989) ) based on the Hallidayan distinction between the textual and interpersonal macro-functions of language. Williams (n.d.) ) taxonomy comprised three common types: Hedges (e.g.'possibly') and emphatics (e.g.'certainly'); sequencers (e.g.'in the next section') and topicalizers (e.g.'with regard to'); and narrators and attributors (e.g.'according to $\mathrm{X}(2005)$ '). This taxonomy was subsequently elaborated by Kopple (1985) , Crismore (1989) and Crismore et al. (1993) and Crismore et al. (1993) . As Tables 1 and 2 show, their taxonomies consisted of two principal categories: Textual and interpersonal metadiscourse. Textual metadiscourse deals with the organization of discourse, that is, how different pieces of information in a text are connected in a coherent way. Interpersonal metadiscourse is recognised as an important means of facilitating communication between text, producer and receiver. Interpersonal metadiscourse helps a text producer to code his/her attitude towards both text content and text receiver by making the text more reader/audience friendly.

Table 1 Vande Kopple's (1985) Taxonomy of Metadiscourse

Textual Metadiscourse

Text connectives denote semantic relations between main clauses, for example 'however', 'and',

'first' Code Glosses help readers to grasp the meanings of ideational material, or example 'such as', 'e.g.', 'in other words', 'that is'

Interpersonal Metadiscourse

Illocution markers makes explicit discourse acts performed at certain points, for example, 'we think that', 'I claim' Narrators indicate the source of the information presented, for example,'Chomsky said' Validity markers assess the probability or truth of a statement, for example, 'probably', 'absolutely' Attitude markers reveal the writer's attitude to propositional contents, for example,'suprisingly', 'great' Commentaries address readers directly and draw them into an implicit dialogue, for example, 'As you know'

Hyland (2004) and Hyland and Metadiscourse (2005) rejected the strict duality of textual and 
Table 2 Crismore's (1989) Taxonomy of Metadiscourse

\begin{tabular}{|c|}
\hline Textual Metadiscourse \\
\hline Textual Markers \\
\hline $\begin{array}{l}\text { Logical connectives show connections between ideas, for example, 'therefore', 'soSequencers show } \\
\text { sequence or ordering, for example, 'first', 'second' Reminders give references to previous } \\
\text { information, for example, 'as said before' Topicalizers indicate shifts in topic, for example, 'now we } \\
\text { shall focus on' }\end{array}$ \\
\hline Interpretive Markers \\
\hline $\begin{array}{l}\text { Code Glosses further explain text material, for example, 'for instance' Illocution markers name the } \\
\text { act performed, for example, 'in conclusion' Announcements announce upcoming information, for } \\
\text { example, 'in the following table' }\end{array}$ \\
\hline Interpersonal Metadiscourse \\
\hline $\begin{array}{l}\text { Hedges show uncertainty about the truth of a claim, for example, 'suppose' Certainty markers } \\
\text { express commitment to a claim, for example, 'undoubtedly', 'certainly Attributors give the source } \\
\text { or support of a claim, for example, 'according to Hyland (2005)' Attitude markers display the } \\
\text { writer's values, for example, 'luckily' Commentary markers establish a relationship with the reader, } \\
\text { for example, 'my dear readers' }\end{array}$ \\
\hline
\end{tabular}

interpersonal metadiscourse found in the previous taxonomies. According to Hyland (2004), "all metadiscourse is interpersonal in that it takes account of the reader's knowledge, textual experiences, and processing needs and that it provides writers with an armoury of rhetorical appeals to achieve this". In other words, text producers use textual metadiscourse not only to create textual links but also to guide or direct their readers or audiences through the text and make them aware of the writer's stance or attitude towards the text content in order to persuade them. Textual metadiscourse is therefore multifunctional and textual metadiscourse markers serve both textual and interpersonal functions.

This current study takes Hyland and Metadiscourse (2005) taxonomy of metadiscourse as its theoretical framework. Hyland's (ibid.) taxonomy was based on THOMPSON and THETELA (1995) distinction between interactive and interactional resources to acknowledge the organizational and evaluative features of interaction Hyland and Metadiscourse (2005) . As will be seen in Table 3 below, this taxonomy consists of two major categories: interactive and interactional metadiscourse. Interactive metadiscourse deals with the text producer's management of the information flow to guide the text receiver through the text. Interactional metadiscourse is more personal and expresses the text producer's stance and his/her interaction with the text receiver.

Asides are one of the engagement markers in this taxonomy. They are short dialogues between

the text producer and receiver (Hyland and Metadiscourse (2005), Marković (2013) ). They are generally presented in brackets, parentheses or dashes. Hyland and Metadiscourse (2005) stated that a text producer uses them to address his/her text receivers directly by briefly interrupting the argument to insert his/her personal comments on the subject. In this way, writers can emphasize their point of view and 
Table 3 Hyland's (2005) Taxonomy

Interactive Metadiscourse guides the reader through the text

Transitions denote semantic relations between main clauses, for example, 'moreover,' 'and', 'but' Frame Markers are used to refer to text stages, sequences and discourse acts, for example, 'first', 'finally', 'in conclusion' Endophoric Markers refer to information in other parts of the text, for example, 'as seen in Table 4', 'as mentioned above' Evidential Markers refer to sources of information from other texts, for example, 'according to X', '(Y, 1990)' 'Z states' Code Glosses help readers to grasp functions of ideational material, for example, 'e.g., 'such as', 'in other words', 'that is'

Interpersonal Metadiscourse involves the reader in the text

Hedges express partial commitment to the truth or value of the text. Information is presented as an opinion rather than a fact, for example, 'assume', 'suppose', 'probably'Boosters express total commitment to the truth or value of the text; in other words, they show the text producer's certainty about the topic, for example, 'undoubtedly, 'clearly'Attitude markers express the text producer's lack of conviction about the text to the receiver, for example, 'unfortunately', 'remarkably Self-mention refers to the author(s), for example. 'I', 'me', 'we' Engagement markers build a relationship with the text receiver both to stress solidarity and to position the receiver by anticipating possible objections and guiding their thinking. They include reader pronouns, asides, references to sharedness, directives and questions, for example, 'consider', 'note that'

shape their readers' or audiences' opinion. These short dialogues add more to the relationship between text producer and text receiver than to the propositional development. They are therefore seen as a key reader-oriented strategy (ibid.).

Previous metadiscourse investigations have primarily focused on persuasive writings or speech produced in a number of different contexts such as textbooks (for example, Crismore (1984) ; Hyland (1999) , academic research articles (for example, Hyland (2004) ; Dahl (2004) ; Akbaş (2012) ), post-graduate dissertations (for example, Bunton (1999) ) and casual conversation (for example, Schiffrin (1980) ). Neverthless, a few studies (for example, Ilie and Discourses (2006) ; Ismail (2012) ; Temmerman (2013) ) have investigated the function of metadiscourse markers in political speech and political interviews which are one of the most important examples of the persuasive text genre.

The political interview is considered to be a genre whose communicative purpose is to convince and persuade the audience or reader. Lauerbach (2007) defined the goals of the interviewer and interviewee in a political interview as follow:

... the interviewer wants to provide an up-to-date and appealing perspective on the events concerned and on their main protagonists, while the interviewee (here primarily a politician) - in exchange for information and opinion - wants to realize good publicity.

According to Mcnair (2011) , "there is a relationship of 'mutual convenience and interdependence' between interviewer and interviewee, because interviewee should satisfy interviewer's hunger for news while maximising their own favorable public exposure.

Fetzer and Minister (2006) defined a political interview as the negotiation of validity claims. According to Fetzer (ibid.) a political interview consists of two dif- 
ferent frames of interaction which occur simultaneously: the first-frame interaction between the interviewer and the interviewee, and the second-frame interaction between the first-frame participants and the audience/reader. Andone (2010) stated that although at all times the discussion takes place between the interviewer and the politician, their primary addressee is the audience/reader at home. They try to convince or influence the listening, reading or television-watching audience. For politicians, this means the other party's members and supporters as well as their voters; for interviewers, this is their colleagues and their readers or audiences. Therefore, the political interview consists of three participants and involves four-directional communication (interviewer-interviewee, interviewee-interviewer, interviewer-reader/audience, interviewee-reader/audience) (Temmerman (2013) ).

Interviews are classified in terms of the information transmitting channel: oral or written. In television and radio interviews, the channel is oral so the communication between the participants is more direct. Audiences can participate in a television or radio programme by telephone or they can be present in the studio in which the interview is being held. In newspaper interviews, the channel is written and indirect because the conversation between the interviewer and interviewee is transcribed by the interviewer and the audience can only access this printed version of the conversation (Temmerman (2013); Toleukhanovna (n.d.) ).

Interviewers have more advantages than intervieweees in a written interview. Interviewers plan

and control the interview and ask prepared questions to which the interviewee must reply spontaneously. Then, after the recorded interview, the interviewer can decide which parts are to be deleted from the interview, but the final interview text does not contain anything not said by the interviewee (Esmer (n.d.); Temmerman (2011) ). Interviewers should be impartial and objective, but they should also be adversarial and should challenge the interviewee (Toleukhanovna (n.d.) ). Thus, they try to convince or persuade their readers/audiences. Иньиго-Мора (2008, 34, cited in Toleukhanovna (n.d.) ) suggested that they must conform to the norm of adversarialness by asserting and expressing their personal opinion and resorting to forms of affiliative behavior.

Asides are usually added to written interviews by interviewers to express their comments on the subject under discussion. According to Goffman (1981); Temmerman (2011) , journalists might use asides to represent their interviewee as a friendly person; they might also use them to show their readers that they are competent journalists capable of asking searching questions. Temmerman (2013) also stated that in newspaper political interviews, asides are used as a way of corroborating the competence of the interviewer and that they have five different functions in a text:

1. Adding factual information which the reader cannot be presupposed to have;

2. Describing the setting in which the interview takes place;

3. Describing the non-verbal behavior of the interviewee; 
4. Describing emotions shown by the interviewee; and

5. Assessing the conversational behavior of the interviewee

Crismore and Abdollehzadeh (2010) commented that countries outside Europe and the US have paid little attention to newspapers as a genre or to metadiscourse analysis. The Turkish literature survey revealed that only a few studies (for example, Esmer (n.d.); Temmerman (2011) ) have been conducted on the presence and function of metadiscourse markers in Turkish newspaper discourse. Moreover, during the literature survey, no study was found on the function and role of asides in Turkish newspaper political interviews. The need for such a study is therefore clear. The current study is designed to analyse the use of asides in newspaper political interviews conducted with prominent politicians in Turkey. It is hoped that the findings will contribute greatly to Turkish metadiscourse studies for all the reasons mentioned above.

\section{METHODOLOGY}

\subsection{RESEARCH DESIGN}

The study used a descriptive survey model which enabled the researcher to identify the characteristics of the observed phenomenon as-is Baškarada (2014) ). Quantitative and qualitative methods were applied using both Corpus Linguistics (CL) and Critical Discourse Analysis methodologies (CDA). CDA provided the qualitative research tools and CL provided the quantitative research tools for the study of discourse.

Today, the use of the CL methodology has become widespread in CDA (Baker et al. (2008) . Baker, Gabrielatos, KhosraviNik, Krzyzanowski, McEnery and Wodak (2008, 296) stated that "CL examine frequencies, or, at least, provide strong indicators of the frequency, of specific phenomena recognized in CDA (e.g., topoi, topics, metaphors), by examining lexical patterns, and can add a quantitative dimension to CDA". During the literature survey, it was realized that the total number of both CL and CDA studies on metadiscourse is considerably limited in proportion to the number of CL studies. This current study was therefore framed in both the CL and CDA perspectives.

\subsection{DATA AND ANALYSIS}

The data for this study comprised eigthy political interviews published from January 2011 to

January 2021 in seven randomly selected elite mainstream newspapers which had different ideologies, four of them pro-government (Yeni Şafak, Habertürk, Hurriyet and Milliyet) and the others anti-government (Sözcü, Cumhuriyet and Türk Solu).

The data analysis was based on Temmerman (2013) classification of asides and Hyland and Metadiscourse (2005) metadiscursive taxonomy. The corpus was analysed using the NooJ linguistic engine module which allows users to process large sets of texts in real time and to formalize various types of textual phonemena 
such as orthography, lexical and productive morphology, and local,structural and transformational syntax. The program also allows users to carry out statistical analyses such as frequency and standard score. During the data analysis, all of the interview texts in the corpus were uploaded into Nooj. Then the type and frequency of the asides in the corpus were determined.

\section{RESULTS AND DISCUSSIONS}

The quantitative analysis showed that the total number of asides used in the corpus was 113 and

that their frequency order and their functions were quite different. Asides were employed far more frequently by the pro-government journalists and the statistical difference between the two sets of data $(p=0.048<0.05)$ is significant. The results are shown in Table 4

\begin{tabular}{|c|c|c|c|}
\hline Asides & $\begin{array}{l}\text { Interviews in } \\
\text { Pro-government } \\
\text { newspapers }\end{array}$ & $\begin{array}{c}\text { Interviews in } \\
\text { Anti-government } \\
\text { newspapers }\end{array}$ & Chi-Square Results \\
\hline $\begin{array}{l}\text { Adding factual } \\
\text { information } \\
\text { which the reader } \\
\text { is not } \\
\text { presupposed to } \\
\text { have }\end{array}$ & 54 & 45 & 0.0423 \\
\hline $\begin{array}{l}\text { Describing the } \\
\text { setting in which } \\
\text { the interview } \\
\text { takes place }\end{array}$ & - & - & - \\
\hline $\begin{array}{l}\text { Describing the } \\
\text { nonverbal } \\
\text { behavior of the } \\
\text { interviewee }\end{array}$ & 43 & 9 & 0.0267 \\
\hline $\begin{array}{c}\text { Describing } \\
\text { emotions shown } \\
\text { by the } \\
\text { interviewee }\end{array}$ & - & - & - \\
\hline $\begin{array}{l}\text { Assessing the } \\
\text { conversational } \\
\text { behavior of the } \\
\text { interviewee }\end{array}$ & 4 & 1 & 0,479 \\
\hline$p=0.046<0.05$ & & & \\
\hline
\end{tabular}

Table 4 shows that the aside function 'adding factual information which the reader is not presupposed to have' occupied a high position in both sets of data but was used more by pro-government interviewers.

As can be seen in examples (1) to (4), the aside function was heavily used by the pro- and anti-government journalists in an impartial manner. The interviewers did 
Interviews in Anti-government newspapers (Example 1)

Hüseyin Yayman bizi bugün Adıyaman milletvekili olan Adnan Bey [Boynukara] ile buluşturdu. 'Today, Hüseyin Yayman brought me together with Adnan Bey [Boynukara] the deputy from Adiyaman.' (Cumhuriyet interview conducted with Altan Tan, who was deputy leader of the Democratic Party of the peoples (HDP) in 2012)
Interviews in Pro-government newspapers (Example 4)

Bunu ABD'li yetkililere de söylüyoruz. Biden'a da [ABD Başkan Yardımcısı Joe Biden] telefonda Israrla iade etmeleri gerektiğini söyledim. 'We denounce him to the authorities of the United

States of America. I also persistently told Biden

[Joe Biden is the US vice-president] on the phone that they should extradite him to Turkey.'

(Habertürk interview conducted with the former prime minister Binali Yıldırım in 2016)

(Example 2)

Tam gün yasasının tartışıldığı dönemde ben şunu isterdim; her taraf [yönetenler, iktidar, sağlıkla ilgili oda temsilcileri, hekim temsilcileri ve üniversiteler] bir masa etrafında tartışabilselerdi. 'When the law of full-time employment was being negotiated, I wished that all sides [the ruler, universities, doctors and medical respresentatives] could sit down and discuss it around a table.' (Sözcü interview conducted with the opposition Republican People's Party (CHP) deputy Gürsel Tekin in 2014)

(Example 3)

Bu tavır bana yabancı değil. 116 karanlık günü

[Erdoğan'ın 2002'de Baykal'ın desteğiyle milletvekili seçilerek Başbakan olduğu dönem] her zaman sorarım, cevabını isterim, veren de olmadı. "This attitude is familiar to me. I always ask about the 116 dark days [the interval between Erdoğan being elected and becoming prime minister with the support of Baykal] and expect a response, but nobody responded.'

(Sözcü interview conducted with the opposition Nationalist Movement Party (MHP) leader Devlet Bahçeli in 2014)

not express their opinions about the issues being discussed and did not reflect their attitude towards the interviewees. They only gave explanatory information or details about the issues. Even so, there were some instances in the pro-government data, such as the example ( 5 ), in which the aside No leader ever went to every part of Turkey was used to show the interviewer's attitude towards the interviewee. In this particular aside, the interviewer showed appreciation for the politician's effort and in this way he denoted his sympathy for the government's policy implementations.

Moreover, as shown in Table 4 , the aside function 'describing the non-verbal behavior of the interviewee' occupied second position in the corpus, although it was less used by anti-government interviewers. The most used non-verbal behavior in the corpus was laughter alone, with shared laughter taking second position. The non-verbal behavior eyes filled with tears was the least used and was only observed in the pro-government interviews.The findings on non-verbal behavior are set out in 


\section{Graph 1 .}

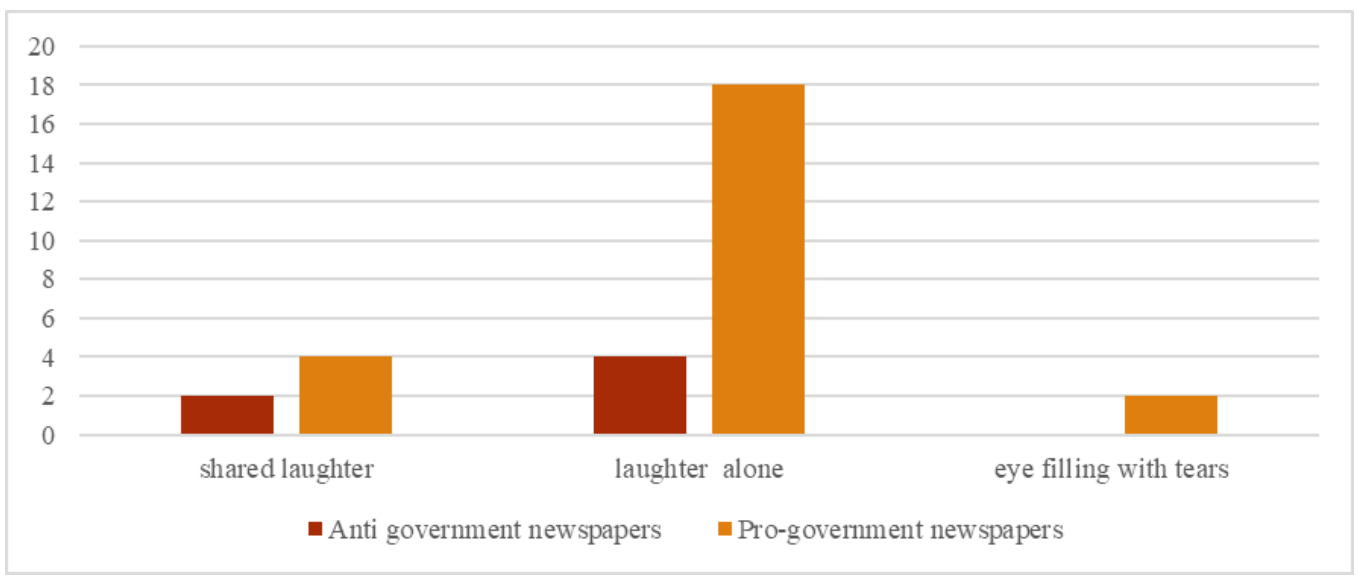

\section{Graph 1: The frequency of the non-verbal behaviors observed in the corpus.}

As can be seen in the following examples (6) and (7), the words gülüşmeler and kahkahalar (laughter) denote shared laughter which is invited and accepted by both parties in an interview. Using these words as asides indicated the rapport between the interviewer and the politician. In other words, by including these asides, the interviewers tried to represent the interviewee as a friendly person. They also denoted that the interviewer understood the politician's orientation to winning to the reader's (the voter's) appreciation.

Interviews in Anti-government newspapers (Example 6)

Ü. Yaltırık (The journalist in Türksolu): Ya başarılı olamazsanız? 'What if you fail?' R.T. Erdoğan (the Former prime minister and now the President of Turkey): 0 zaman yeni bir seçim daha yaparız! [Gülüşmeler]. 'Then we

hold a new election! [Laughters]' (The interview in Türksolu newspaper conducted with the president Recep Tayyip Erdoğan by Yaltırık in 2012)
Interviews in Pro-government newspapers (Example 7)

K. Par (The Journalist in Habertürk) MHP'den aday olduktan sonra bozkurt işaretini yapamamanız espri konusu oldu! 'After becoming a candidate for the MHP, you couldn't make the sign of Bozkurt (a mythological sacred animal) and so you became a figure of ridicule.' Ekmeleddin (The opposition party MHP president nominee): 0 gün antrenmansızdım. Canım biraz da Twitter'dakilere malzeme vermiş olalım! [Kahkahalar]. 'That day, I was out of practice. Let's supply those on twitter with some material [Laughters].' (The interview in Habertürk newspaper conducted with Ekmeleddin İhsanoğlu by Par in 2012)

In the following examples (8) to (11), the words gülüyor (he/she laughs) and gülerek (laughingly) indicate non-shared laughter (laughing alone). It can be seen that the politician laughed alone after a difficult question posed by the interviewer. With the help of this non-verbal behavior, the politician tried to respond to the awkward question by acknowledging and trying to alleviate the tension. In other words, he tried to lessen the impact of a face-threatening exchange. By including the statements as an aside, the journalist wanted to show readers and colleagues that he had asked a good question which made the politician feel cornered and was therefore a 
competent interviewer.

Interviews in Anti-government newspapers (Example 8)

S. Ongun (The journalist in Cumhuriyet): Hakkınızda kaç fezleke var? 'How many summary proceedings have there been about you?' S. Demirtaş (the opposition party (HDP) leader): 87 sanırım. Son 10 fezlekem oylamanın tamamlanmasından hemen önce yetiști. [Gülüyor] 'I guess. The last ten arrived just before the voting was completed [he laughs].' (The interview in Cumhuriyet newspaper conducted with Selahattin Demirtaş by Ongun in 2016)
Interviews in Pro-government newspapers (Example 10)

A. Selvi (The journalist in Yenișafak): Kılıçdaroğlu masaya yumruğunu vuracağını söyleyerek güçlü görüntü oluşturmaya çalıștı. Erdoğan'a mı öykündü? 'Kılıçdaroğlu pretended to be powerful, saying that he will bring the matter to the table. Is he imitating Erdoğan?

$\mathrm{M}$. Ince (the opposition party CHP deputy):

Bilemiyorum. [Gülerek] Belki bana kızmıș olabilir. 'I don't know. [Laughingly] Maybe he was angry with me.' (The interview in Yenişafak newspaper conducted with Muharrem Ince by Selvi in 2014)

(Example 9) (Example 11)

İ.Özbey ( The journalist in Cumhuriyet Newspaper): Anket sonucu hemen akla "Akşener cumhurbaşkanı olur mu" sorusunu getiriyor. Böyle bir planınız var mı? "The result immediately brings to mind the question, "Will Akşener be president?" Do you have such a plan?" M.Akșener (The former deputy in the MHP and now the opposition Good Party leader): (Gülerek) Bunları seçim gündeme gelsin, o zaman konuşuruz. "(Laughing) Let them be on the agenda, then we'll talk." (The interview in Cumhuriyet newspaper conducted with Meral Akșener by Özbey in 2020)
K. Par (The journalist in HabertürkNewspaper): Ailedeki MHP'lilerle aranız nasıl? 'Can you agree with your relatives who support the MHP?' F. Yüksekdağ (The opposition party HDP former co-chairman): Firsat buldukça bir araya geliyoruz. Farklı ideolojik çizgilerde olsak bile ailemin sağ kesiminde olanları da akrabalarım olarak sahipleniyorum. Onlar da 'anarşist Figen'i hep sahiplendiler! [Gülüyor] 'We come together when we get a chance. Although we have different ideologies, I see the right-wingers in my family as my relatives as well. They have always embraced the 'anarchist

Figen' [She laughs]. (The interview in Habertürk newspaper conducted with Figen Yüksekdağ by Par in 2015)

In the next example below, the phrase gözleri doluyor ('his eyes fill with tears') was used to show that the politician became emotional during the interview. By describing this non-verbal behavior of the interviewee, the interviewer tried to represent the interviewee as a friendly and emotional person. There was no usage of this particular form of non-verbal behavior in the anti-government set of data.

Interviews in Anti-government Interviews in Pro-government newspapers (Example 12) newspapers

Kone $\quad$ Par (The journalist in Habertürk Newspaper): Evdeki
rutin nasıl etkilendi? 'How were the routine activities at
home affected? O. Vural (The opposition party MHP
deputy): Akşamları dișarı çlkmayı sevmezdim, bir an önce
eve gideyim isterdim. 'Tuba bir çay koy' derdim. Ama o şu
anda yok ... Epey uzunca bir süredir eve sadece yatmaya
gidiyoruz. Evin sahibesini bekliyoruz ... [Gözleri doluyor].
'I never used to go out at nights. I used to go home as soon
as possible. I used to say 'Tuğba, prepare the tea'. But now
it is impossible. ... for a long time, I go home just to sleep.
I wait for the mistress of the house [His eyes filled with
tears]. (The interview in Habertürk newspaper conducted
with Oktay Vural by Par in 2015)


The aside function 'assessing the conversational behavior of the interviewee' was used only three times by pro-government journalists. There was no usage of this function in the anti-government interviews. The phrases bir süre duraksıyor ('he is hesitating for a while') and düşünüyor ('he is thinking') in the examples (13) and (14) indicated that the politicians were preparing what to say next and formulating their replies. In the example (13), by using the phrase as an aside the interviewer showed the readers that the politician was a thoughtful person who used this particular nonverbal behavior to give himself time to think. In the example (14), the aside he is thinking for a while, the question which I asked forces a dilemma showed that the politician was planning how to answer the question. In other words, he was trying to find suitable words because the interviewer had posed a difficult question. The use of this particular aside by the interviewer was to show that he is a competent journalist and that he could ask a question which put the politician on the spot.

Interviews in Anti-government Interviews in Pro-government newspapers (Example 13) newspapers

None

K. Par (The interviewer in Habertürk): Meme kanserini atlattı derken metastaz mı yaptı? 0. Vural (The opposition party MHP deputy): Evet, nedenini bilmediğimiz bir șekilde tekrar nüksetti. Şimdi tedavisi devam ediyor [Bir süre duraksıyor] Allah'a şükür ... 'Yes, I don't know why, but she had a relapse. And now, she is receiving treatment [he is hesitating for a while] Thanks be to God. (The interview in Habertürk newspaper conducted with Oktay Vural by

Par in 2014) (Example 14) Çapa (The interviewer in Mecmua Magazine): Çok iyi bir ikinci adam ama birinci adam değil. Hangisisiniz? [Gürsel Tekin ilk kez düşünüyor. Eh soru da zaten yukarı tükürsen bıyık, aşağı doğru sakal durumu]. 'A very good second man, but not the first man. Which one identifies you? [For the first time, Gürsel Tekin is thinking. The question is too difficult in any event]. (The interview in Milliyet newspaper conducted with Gürsel Tekin by Çapa in 2011)

\section{CONCLUSIONS AND RECOMMENDATIONS}

The quantitative analysis of the data showed there were some variations in the use and distribution of the asides in the two sets of data. The variations observed in the data could be attributed to the ideological viewpoint of the newspapers as well as of the interviewers. The asides were used infrequently by the anti-government journalists. The anti-government journalists generally favored the use of the aside function 'adding factual information which the reader is not presupposed to have'. Similar to Temmerman's (2013) findings, in the anti-government interviews we did not find any instances of the technique of using asides to show appreciation of an interviewee's replies or the interviewer's questions. It was found that the journalists preferred to avoid the assertion of their own opinions and to disaffiliate from their interviewees and also from their readers. The results have shown that anti-government interview- 
ers tried to show respect for their readers (especially readers with different political views) by keeping their distance from them and communicating with their readers by leaving an alternative view open.

In the pro-government interviews, asides were used more frequently, and unlike the anti-government interviews, the technique of using asides showing 'appreciation of the interviewer's questions and the interviewee's replies' was found. It was also found that they preferred to affiliate with their interviewees. The results showed that they tended to more clearly express their personal feelings, concerns and commitment. It can therefore be said that the pro-government interviewers were more assertive and more willing to communicate with their readers than the anti-government interviewers.

This study was conducted using descriptive research and focusing on an analysis of asides in Turkish political newspaper interviews, and this methodology is thought to pioneer future studies on asides. However, the study was limited to seven newspapers and the analysis of written newspaper political interviewers. It is therefore suggested that future studies could use different focuses and could be carried out by expanding the size of the newspaper corpus to see if similar results are obtained. In addition, other contrastive studies could be conducted to compare newspaper and magazine interviews.

\section{REFERENCES}

Ädel, A., \& A. Metadiscourse in L1 and L2 English (Vol. 24). John Benjamins Publishing; 2006. (2006). A. Metadiscourse in L1 and L2 English (Vol. 24). John Benjamins Publishing; 2006. Metadiscourse in L1 and L2 English, 24, 243-243.

Akbaş, E. (2012). Interactional Metadiscourse in Turkish Postgraduates' Academic Texts: A Comparative Study of How They Introduce and Conclude. Journal of English Language Teaching, 2(3), 35-45.

Andone, C. (2010). Maneuvering strategically in a political interview: analyzing and evaluating responses to an accusation of inconsistency. Amsterdam: SicSat, 147-147.

Baker, P., Gabrielatos, C., Khosravinik, M., Krzyzanowski, M., Mcenery, T., \& Wodak, R. (2008). A Useful Methodological Synergy? Combining Critical Discourse Analysis and Corpus Linguistics to Examine Discourses of Refugees and Asylum Seekers in the UK Press. Discourse and Society, 19(3), 273-296.

Baškarada, S. (2014). Qualitative Case Study Guidelines. The Qualitative Report, 19(40), 1-18. Retrieved from https://dx.doi.org/10.46743/2160-3715/2014.1008 10.46743/2160 $-3715 / 2014.1008$

Bunton, D. (1999). The use of higher level metatext in Ph.D theses. English for Specific Purposes, 18, S41-S56. Retrieved from https://dx.doi.org/10.1016/s0889-4906(98) 00022-2 10.1016/s0889-4906(98)00022-2

Crismore, A. (1984). The Rhetoric of Textbooks: Metadiscourse. Journal of Curriculum Studies, 16(3), 279-296. Retrieved from https://dx.doi.org/10.1080/0022027840160306 10 $.1080 / 0022027840160306$

Crismore, A. (1989). A.Talking with readers: Metadiscourse as rhetorical act. New York., 294- 
294.

Crismore, A., \& Abdollehzadeh, E. (2010). A Review of Recent Metadiscourse Studies: The Iranian Context. Nordic Journal of English Studies, 9(2), 195-195. Retrieved from https:// dx.doi.org/10.35360/njes.223 10.35360/njes.223

Crismore, A., Markkanen, R., \& Steffensen, M. S. (1993). Metadiscourse in persuasive writing: A study of texts written by American and Finish university students. Written Communication, 10(1), 39-71.

Dahl, T. (2004). Textual metadiscourse in research articles: a marker of national culture or of academic discipline. Journal of Pragmatics, 36(10), 1807-1825.

Esmer, E. (n.d.). Interpersonal Metadiscourse Markers in Turkish Opinion Articles Published in Pro- and Anti-Government Newspapers. In T. Balcl, A. Öztürk, \& M. Aksöz (Eds.), Schriften zur Sprache und Literature IV (Vol. 2020, pp. 351-361). IJOPEC Publication Limited.

Fetzer, A., \& Minister. (2006). we will see how the public judges you. Media references in political interviews. Journal of Pragmatics, 38(2), 180-195.

Goffman, E. (1981). E. Forms of talk. Oxford: Blackwell., 335-335.

Halliday, M. A., \& owards a Sociological Semantics', Working Papers and Prepublications C014. Centro Internazionale di Semiotica e Linguistica, University di. (1994). Towards a Sociological Semantics. Working Papers. Retrieved from https://semiotica.uniurb.it/ wp-content/uploads/2013/09/14-C-2.pdf

Harris, Z. S. (1959). The transformational model of language structure. Anthropological Linguistics, 1(1), 27-29.

Hyland, K. (1999). Talking to students: Metadiscourse in introductory coursebooks.English for Specific Purposes. Talking to students: Metadiscourse in introductory coursebooks, $18,3-26$.

Hyland, K. (2004). Metadiscourse in Academic Writing: A Reappraisal. Applied Linguistics, 25(2), 156-177. Retrieved from https://dx.doi.org/10.1093/applin/25.2.156 10 .1093 /applin/25.2.156

Hyland, K., \& Metadiscourse. (2005). Exploring interaction in writing. Oxford: Continuum, 230-230.

Ilie, C. P., \& Discourses. (2006). Parliamentary Discourses. In Encyclopedia of Language and Linguistics (2nd edition) (Edited by K.Brown). Oxford: Elsevier. Encyclopedia of Language and Linguistics, 9, 188-197.

Ismail, M. H. (2012). Discourse Markers in Political Speeches: Form and Functions. Journal of the College for the Education of Women, 23(4), 1260-1278.

Kopple, W. J. V. (1985). Some Exploratory Discourse on Metadiscourse. College Composition and Communication, 36, 82-82. Retrieved from https://dx.doi.org/10.2307/357609 $10.2307 / 357609$

Kopple, W. J. V. (2002). Metadiscourse, discourse, and issues in composition and rhetoric. In E. Barton, , \& G. S. Gresskill (Eds.), Discourse studies in composition (pp. 91-114). Hampton Press.

Lauerbach, G. (2007). Argumentation in political talk show interviews. Journal of Pragmatics, 39(8), 1388-1419. Retrieved from https://dx.doi.org/10.1016/j.pragma.2007.04.004 10.1016/j.pragma.2007.04.004

Marković, J. M. (2013). Engagement Markers in Introductory Textbooks. Komunikacija i kultura online. Engagement Markers in Introductory Textbooks. Komunikacija i kultura online, 4, 36-51.

Mauranen, A. (1993). Contrastive ESP rhetoric: Metatext in Finnish-English economics texts. 
English for Specific Purposes, 12, 3-22. Retrieved from https://dx.doi.org/10.1016/ 0889-4906(93)90024-i 10.1016/0889-4906(93)90024-i

Mcnair, B. (2011). An Introduction to Political Communication. Routledge: London, 25-25.

Schiffrin, D. (1980). Meta-Talk: Organizational and Evaluative Brackets in Discourse. Sociological Inquiry, 50(3-4), 199-236. Retrieved from https://dx.doi.org/10.1111/j.1475 -682x.1980.tb00021.x 10.1111/j.1475-682x.1980.tb00021.x

Temmerman, M. (2011). The representation of competence in newspaper interviews: a linguistic-pragmatic discourse analysis of the (self-)representation of journalists and politicians in written interviews. In K. Pelsmaekers (Ed.), Displaying competence in organizations: A discourse perspective (pp. 113-141). Palgrave Macmillan.

Temmerman, M. (2013). he representation of competence in newspaper interviews: a linguistic-pragmatic discourse analysis of the (self-)representation of journalists and politicians in written interviews. In Displaying competence in organizations: A discourse perspective. (Edited by K. Pelsmaekers). Forms and functions of asides in print media interviews, 370-371.

THOMPSON, G., \& THETELA, P. (1995). The sound of one hand clapping: The management of interaction in written discourse. Text - Interdisciplinary Journal for the Study of Discourse, 15(1), 103-130. Retrieved from https://dx.doi.org/10.1515/text.1.1995.15.1 .103 10.1515/text.1.1995.15.1.103

Toleukhanovna, T. A. (n.d.). Linguistic and social gender in political discourse: a contrastive analysis of the Greek, Kazakh and Russian languages." (Unpublished doctoral dissertation). Linguistic and social gender in political discourse: a contrastive analysis of the Greek, Kazakh and Russian languages." (Unpublished doctoral dissertation), 2010, 371371.

Williams, J. M. (n.d.). Ten Lessons in Clarity and Grace. Boston: Scott Foresman., 1981, $123-$ 123. 